\title{
IMAGE CRISIS IN LEGIA \\ WARSZAWA SPORTS KLUB \\ FOLLOWING ACCUSATIONSOF ATTACKING MEMBERS OF HAPOEL PETAH TIKVA TEAM BY LEGIA'S FANS - SITUATION ANALYSIS AND EVALUATION
}

Krzysztof Łapiński' ${ }^{1}$ Marcin Mastalerek ${ }^{2}$

\section{Abstract}

Today sports plays a very important role in marketing, brand image building and also in the entire promotion process in organizations. In order to obtain the planned and crucial for every entity involved effects, there should be the relationship between the product and the sport [Pogorzelski, 2010, p 14]. Not every sport provides the opportunity of shaping the image safely and at the level expected by the entity involved.

Keywords: brand image, sport, football, Legia Warszawa.

\section{Introduction}

One of the sports that due to its mass nature, enormous popularity or the number of potential fans may bring the image-related benefits is football (or soccer, as it is called in North America). In Poland, similarly to many other countries, it is the number one sport in terms of popularity. For this reason, it is reasonable that many football clubs, especially those participating in the Ekstraklasa league or aspiring to join it, resemble professionally managed companies with annual budgets estimated at tens of millions of the Polish zloty. The budget of the current Polish championship holder - Legia Warszawa - exceeds PLN 100 million (ca. EUR 23.2 million). In its annual review of football finance "Football Money League 2017", one the world's largest consulting firm Deloitte informs that the combined revenue of Ekstraklasa clubs amounted to over PLN 550 million (ca. EUR 127.7 million) in 2017, while 10 years earlier it was only PLN 200 million (ca. EUR 
46.5 million) [2.deloitte.com, 2018]. Together with player transfer receipts, that amount grows to PLN 695 million (ca. EUR 161.4 million).[2.deloitte.com, 2018] This demonstrates both the growth rate and the potential for development in the Polish club football in the future.

The past few years have brought professionalization in the management and operation of clubs. Their owners have introduced the rules of the business world. A considerable part of the Polish Ekstraklasa clubs have modern and safe stadiums. They have special VIP facilities with skyboxes, which are a source of income on one hand and attract business clients on the other. Advertisements on boards surrounding the stadiums or on T-shirts, titular sponsorship of stadiums, revenues from the sale of television broadcasting rights, club souvenir and gadget sales, the sales of season and match tickets, income from player transfers and from the so-called match day are important sources of club revenues. Clubs are also becoming more open and bolder in using modern technologies to attract fans and for self-promotion purposes. Football clubs are independent brands today that have to build their image professionally, similarly to other businesses.

When the image is built in a professional way and the club triggers positive and expected associations, it is easier to find sponsors and attract fans to every match. For many years, Polish football clubs have successfully attracted families with children and business clients to stadiums. For this reason, each club should be interested in building a positive image and spreading confidence that the stadium is a safe place, where whole families can watch a football match in a relaxed and friendly environment, buy club souvenirs and gadgets, or enjoy the foodservice offer.

Like any other organization, also football clubs are exposed to the risk of crisis situations that have adverse effect on their image. The literature defines crisis as a phenomenon triggered by a range of various causes. Most often it is not possible to point at and identify only one cause that contributes to the crisis situation [Tworzydło, 2017, p. 169]. Crisis is the situation that jeopardizes the stability of company operations. (...) In the practice of public relations, crisis first threatens the company image, that is the way it is perceived in the internal and external environment. The such understood image crisis may also jeopardize the actual existence of a company, lead to the discontinuation of its functions and, ultimately, to bankruptcy [Tworzydło, 2008, p. 91]. As emphasized by crisis management practitioners and theorists, even the best-managed organizations that seek to prevent crisis situations, have to face them sooner or later. The difference is that they are properly prepared for such a challenge, have relevant procedures, the management and employees have received adequate training and, consequently, they know how to ride out the crisis period safely. However, there also organizations that, for a variety of reasons, downplay the risk of crisis. When it comes, they often have no knowledge or skills to manage the crisis, which may result in severe losses for the whole organization. Such companies and organizations can be divided into those that have already gone through crisis and those for which crisis is yet to come. (...) Confidence and credibility are the values that need to be protected in crisis situations. Their loss always weakens the company's market position [Podraza, 2008, p. 9]. Crisis management and, when a crisis is discussed by the media, also crisis communication management, is the challenge that many Ekstraklasa clubs have had to tackle in the past few years.

This article presents examples of crises that had a significant impact on the image of the affected clubs. The article aims to demonstrate to what extent and in what way it is possible to respond effectively in the initial phase of the crisis, with particular focus on the problems that affect sports clubs. Several cases have been analyzed, while the leading example is the Legia Warszawa club and public accusations of attacking members of Israel's Hapoel Petah Tikva football team by Legia's fans. Each crisis, and the media-hyped crisis that turns into the image crisis in particular, may lead to severe financial perturbations and, as a result, negatively affect the functioning of the entity involved. Possible consequences of the image crisis are as follows: loss of credibility, 
loss in general trust and the trust of the community in which the club operates, loss of sponsors and business partners, problems with local administration, and other.

\section{Examples of image crises caused by incidents involving football hooligans}

Some image-related crises, also those having financial consequences, are triggered by various instances of public order violations at or outside a stadium. For example, Legia Warszawa was ordered to play their next Champions League match behind closed doors as punishment for crowd trouble during their game with Borussia Dortmund. Although crowd disturbances at the stadium were quickly stopped and did not cause any major losses, the penalty imposed by UEFA and image-related losses were much more painful. UEFA ordered a full stadium closure for Legia'snext match in the elite Champions League with Real Madrid, winner of the Champions League trophy in the previous year and an outstanding favourite to lift it again. The Legia club suffered heavy financial losses due the loss of income from ticket sales. The stadium would undoubtedly be full at such an exceptional event. Also, it lost the match-day income and suffered severe image-related losses, as the reasons of UEFA's decision were broadly covered by the media.

It needs to be noted that Polish clubs, Ekstraklasa's authorities, the Polish Football Association (PZPN) and the government have made significant efforts in recent years to improve the level of safety at stadiums. The issue was discussed at, among others, a meeting called "Round Table - Football in Poland. Development and Safe Stadiums" (Pol: "Okrągły Stół - Piłka nożna w Polsce. Rozwój i Bezpieczne Stadiony"), attended by Prime Minister Mateusz Morawiecki, Minister of the Interior Joachim Brudziński, Minister of Sports Witold Bańka, President of the Polish Football Association Zbigniew Boniek, President of Ekstraklasa SA Marcin Animucki and others. The meeting was aimed to talk about the opportunities and prospects of football development [rmf24.pl, 2018]. New stadiums that meet the European safety standards have significantly contributed to its improvement. It is worth noting that compared to other European countries, Polish stadiums are safe. However, wherever emotions and large numbers of people are involved, the risk of order disturbances cannot be entirely eliminated. And it is various incidents at football matches or incidents that occur outside stadiums, but are initiated by fans, that pose a potential risk of crisis situations that may negatively affect the image of the whole club.

Other crisis situations related to football include, for instance, a PLN 100,000 fine imposed on the Cracovia football club in December 2017 by the League Commission for disturbances caused by its fans. Members of the club were also banned to organize group trips and enter the stadium for two consecutive matches [sport.tvn.pl, 2017]. Following fan fights at the Lech Poznań - Legia Warszawa match, a financial penalty was imposed on the former. The actual costs were, however, much higher, as in such situations, they include also the necessary repair works at the stadium, and the loss of the potential match-day income [sport.dziennik.pl, 2018]. Problems that affect sports clubs often go beyond regional or national borders. One of the examples of extending image-related problems beyond Poland was an offensive banner put up during theEuropean League match between Lech Poznan and Zalgiris Vilnius, saying Lithuanian serf, kneel before the Polish master! [rmf24.pl, 2013]. The incident triggered international repercussions as well, as the match was attended by the Lithuanian ambassador to Poland who demanded an apology from the authorities of the Lech Poznan club [gloswielkopolski. $\mathrm{pl}, 2013]$. All those events turned out to be very costly for the clubs, not only in terms of fines or income losses, but also in terms of a negative impact on the image. The last example also shows that such incidents may have international consequences. This clearly demonstrates the scale of problems that individual incidents may trigger and the scale of challenges faced by sports clubs in the context of image building.

Poland is not the only country that witnesses outrageous scenes of football hooliganism. For instance, in August 2009, vicious clashes between hundreds of rival fans 
took place at a match between Millwall and West Ham. A disciplinary tribunal of the Football Association of England fined West Ham GBP 115,000. The club was also obliged to work with the police and find the culprits [sport.se.pl, 2011]. Violent clashes between fans took place also during one of the West Ham - Chelsea matches. Both clubs had to pay high fines and their images suffered a severe harm [fakt.pl, 2016]. Incidents of football hooliganism can be found in other countries as well. In France, the SC Bastia-Olympique Lyonnais match was abandoned at halftime after home fans invaded the pitch and attacked players. The French league urged the clubs to ban and punish the fans responsible. Another example that not only adversely affected the image of football clubs and football itself, but were also reflected in the financial situation of the clubs involved, was the punishment imposed by UEFA on Champions League participants Olympiakos and Zenit St. Petersburg for the racist behaviour of their fans by ordering stadium sections closed at last-16 matches. Moreover, UEFA fined both the Greek club and Zenit. Racism is a particularly sensitive area. Both the international football authorities, i.e. FIFA and UEFA, and national organizations are committed to addressing and tackling racism in football. Nevertheless, problems related to racism and discrimination appear regularly and have severe consequences for clubs [sporteuro.pl, 2013]. German Bundesliga clubs have been tackling similar problems for years. For example, four of them were punished for the behavior of their fans during league and German Cup games. Bayern Munich was fined EUR 77,000 for five separate incidents of unsportsmanlike conduct by their fans, because of which one of the matches had to be abandoned [bundesliga.goal.pl, 2018].

In fact, football clubs all over Europe have to tackle similar incidents, not only in Poland, France or Germany. The Italian Football Association fined two clubs for racist chanting from their fans to the fans of the opposing team during one of the league games [eurosport.interia.pl, 2010].

The one thing that all the above mentioned situations have in common is consequences. Fines, point deductions (clubs begin a new season with a negative point balance), suspension of the league license, playing matches in empty stadiums, no entry to away games, club exclusion from competition, damage to stadium infrastructure. All these negatively affect the image of sports clubs. Consequently, it may reduce interest in football games due to safety concerns and the resignation of potential sponsors from getting involved in the club and providing it with financial support. For this reason, it is of utmost importance that football clubs take proper actions aimed to identify potential crisis situations, prevent them and, once a crisis breaks out despite all the preventive measures, be able to manage it and, in particular, adopt professional crisis communication measures. Just like any other organization, sports clubs should specify potential crisis situations stemming from both within the organization and outside it. Importantly, clubs should be aware and able to evaluate the impact of individual crisis situations on their image. The better the club is prepared for crisis, the more likely it is to recover from it without any major damage to the image.

Today, it is a must for sports clubs that want to take care of their image professionally to have a proper crisis communication plan, adopted and consistently implemented in crisis management situations. The plan also evaluates potential threats. There are numerous events that may contribute to the development of an image-related crisis in sports clubs, such as:

- incidents at stadiums,

- pre-arranged football hooligan fights; even though held outside stadiums, they may have a damaging effect for the club's image,

- offensive banners or chants at matches,

- various incidents of a racist or antisemitic nature,

- aggressive behaviour towards players caused by poor sports results,

- match fixing/buying allegations, 
- referee bribery allegations,

- unsportsmanlike conduct of footballers on and off the pitch,

- internal conflicts between team members or between the team and its coach,

- sudden contract termination with a player, coach or sponsor,

- conflicts between club shareholders,

- unsuccessful player transfers,

- footballers' accidents and injuries,

terrorist attacks [sport.pl, 2018]

These are only selected examples of potential crisis circumstances that may happen to sports clubs. Each of them carries specific risks for the club, its finances and image. If not addressed properly, or not addressed at all, the above mentioned situations may end up with further escalation of the crisis instead of ceasing it. In 1989 Sam Black wrote that potential crisis situations can be broken down into the 'known unknown' and the 'unknown unknown'. The former includes mishaps owing to the nature of the organisation and its activities that can be predicted. The 'unknown unknowns' are events that cannot be logically predicted and that can come about from unconnected events or unexpected circumstances [Black, 2001, pp. 152-153]. Just like for any organization, this is true also for football clubs.

\section{Legia Warszawa's image-related problems}

This part of the article presents crisis communication activities of the Legia Warszawa football club. The data used in the analysis has been obtained via desk research and in-depth interviews with the representatives of the club.

On August 2, 2017, Israel's Hapoel Petah Tikva football team informed on its Facebook profile about the possibly anti-Semitic incident that followed a friendly with MKS Ciechanow in Sochocin, Poland. "Fascist fans" of the Legia Warszawa club were blamed for the attack on the Israelis, who added a video recording of the hotel monitoring to the post. The recording depicted attackers dressed in Legia's club colours. However, Hapoel Petah Tikva had not contacted Legia to explain the incident. The attack attracted media interest (not only in Poland) and was covered by the biggest news agencies. The following day, the media copied Hapoel's version of the incident [jewishweek.timesofisrael.com, 2017], unverified and not confirmed by the Legia club. That also applied to the non-European media [ctvnews.ca, 2017]. It was one of the problems that could have contributed to the escalation of the crisis. Another issue was that Legia had no chance to address the accusations, as it had not been requested for any explanations or comments. Meanwhile, the spokesman of the Israeli embassy in Poland criticized the attack. The Israeli authorities said that their Minister of Sports and Culture would request the Polish authorities to shed some light on the incident. One of the Knesset Members called upon the Polish ambassador to Israel to take a stance. At the night of 3 to 4 August, the Simon Wiesenthal Center, a Jewish rights group, urged UEFA to respond and take disciplinary measures against Legia Warszawa over the incident. The intervention of such a well-known and respected organization intensified the media interest. The image crisis of Legia Warszawa started to escalate. It went beyond the club itself and spread onto the image of Poland, as that is how the reports of international news agencies were created. Thus, the crisis that evolved around the incident had several aspects:

- accusing football fans of the anti-Semitic attack,

- publicizing he case by the Hapoel Petah Tikva football team, the members of which were injured in the attack,

- the case became public and received broad media coverage, including international media and news agencies, 
- the Simon Wiesenthal Center issued a statement urging the UEFA authorities to punish Legia Warszawa,

- the Israeli embassy to Poland and Israel's Ministry of Sports and Culture took a firm stance on the case and requested the Polish authorities to explain it.

At that phase of the crisis, those were the target groups potentially interested in the event and it is them that Legia Warszawa needed to address its communication activities. In such situations, it is always necessary to take action quickly, even immediately. Bearing that in mind, the club took a proactive approach to address the situation. First, it contacted the MKS Ciechanow club, the local police and the hotel to verify the obtained information. It also worked with the Ministry of Foreign Affairs and the Ministry of the Interior and Administration on the case. On August 3, Legia Warszawa issued a statement with the following key messages:

- there are no grounds to identify the attackers as Legia's fans, as at the time of the incident, the club, along with its fans, was preparing for the qualifying UEFA Champions League match,

- the information published by the media has not been verified and is based solely on the one-sided allegations, which has clearly put the club at risk of image harm,

- Legia requests Hapoel to provide proper clarification of the situation.

From the point of view of Legia Warszawa, explaining the case was not an easy task. The incident took place $70 \mathrm{~km}$ away from Warsaw and the club stadium, Legia had no original recordings and none of the attackers had been arrested or identified by the police.

Beside the ability to take prompt actions, another key to effective crisis communication is openness to the media demonstrated by providing them with reliable and verified information. In principle, it is better to say less then to pass on unverified or, even worse, false information. For this reason, as the club was not certain as to the actual culprits of the attack, its reaction at that stage of the crisis was absolutely right. Legia Warszawa showed that it took the situation seriously, did not downplay it, sought to clear it up as quickly and fully as possible and was ready to cooperate with all organizations interested or involved in the case to explain what had actually happened.

Despite the crisis communication measures, the Legia Warszawa club also took other crisis management steps. The club was well aware that the anti-Semitic assault accusations could result in very serious consequences. Legia's authorities knew that they would harm the image of the club both in Poland and abroad, so the crisis communication was conducted also in English. In crisis situations, it is impossible to communicate with all stakeholder groups, so organizations need to select the most important ones for communication efficiency purposes and address the messages to them [Kaczmarek-Śliwińska, 2015]. The club was aware that its key communication target include the Israelis, UEFA's authorities and the Simon Wiesenthal Center, thus proving its good preparation in terms of the identification of stakeholders that should be number one recipients of its messages aimed to avert the crisis. This is also in line with basic principles of crisis management.

On August 4, Legia Warszawa released another statement in Polish and in English as a response to the Wiesenthal Center's publication. Its key messages are as follows:

- there are no grounds to link the club to the incident,

- the publication is based solely on the one-sided allegations and Legia's earlier response to those false claims has been ignored,

- Legia Warsaw objects to the use of the club's name next to the word 'fascists',

- the club expects that its name will no longer be linked to that event and all the false claim. Otherwise, it will take appropriate legal actions.

In a letter sent to the Hapoel Petah Tikva club on August 4, Legia Warszawa re- 
quested explanation of the situation. At the same time, it continued efforts aimed to canvass the opinion of the European football authorities on the issue. The following day, the Legia Warszawa club submitted an official letter to the Simon Wiesenthal Center requesting that all claims linking the incident with the club were retracted, since there was no evidence suggesting that Legia's fans had been actually involved in the case. Finally, in their correspondence with Legia Warszawa, Hapoel Petah Tikva admitted that their accusations were solely unfounded speculations based on loose comments of several accidental witnesses. After the intervention of Legia Warszawa, Hapoel Petah Tikva published a retraction of their earlier false claims. Relevant statements were published by the media and on Legia Warszawa's official website [eurosport.interia.pl, 2017].

Thanks to the early and effective actions, the Ministry of Foreign Affairs confirmed that the incident was an act of hooliganism, without any anti-Semitic implications [rmf24. pl, 2017]. Legia Warszawa passed on its stance to news agencies, which published the club's clarification of the case. It was later on quoted by the media both in Poland and abroad [usnews.com, 2017]. The Polish and international media replaced the "Legia's fans" phrase with "masked football (or soccer) hooligans". Hapoel Petah Tikva published a retraction of their false claims regarding the incident and admitted that the unfounded speculations were based on the information provided by accidental witnesses. Legia Warszawa published a relevant press release. The Simon Wiesenthal Center published an update of their statement in the official website [wiesenthal.com, 2017]. It stated that no one connected to the team Legia Warsaw or its supporters were involved in the incident and apologized to the club. The statement reads as follows: Following an attack on members of Israel's Hapoel Petah Tikva soccer team, the Simon Wiesenthal Center issued the following updated statement: While the SWC remains deeply concerned about the anti-Semitic attack against members of an Israeli football team following a recent match with MKS Ciechanow in Poland, despite claims by the victims, it now appears that no one connected to the team Legia Warsaw or its supporters were involved - said Dr. Shimon Samuels, SWC International Relations Director. - The Center apologizes to the team and withdraws its call for football authorities to sanction Legia Warsaw - he added." [legia. com, 2017]

On August 7, the Legia Warszawa club released an official statement informing that both the Israeli club and the Simon Wiesenthal Center withdrew their accusations and calls to sanction the Polish club [legia.com, 2017].

Legia Warszawa's prompt actions, both those aimed to clarify the actual course of the incident and those related to crisis communication, allowed to make it unequivocally clear that the fans of the Legia Warszawa football club were not responsible for the attack on the Israeli Hapoel Petah Tikva team. Following Legia's efforts, both Hapoel Petah Tikva and the Simon Wiesenthal Center withdrew their accusation in public and apologized to the club for the unfounded accusaions. Moreover, the SWC withdrew its call onthe UEFA authorities to sanction Legia Warszawa. Had the club failed to take a serious approach to the situation or adopt professional communication measures, such an effect would not be possible. The club did not downplay the accusations and properly identified possible adverse financial and image-related hazards both in Poland and on the international stage. Legia Warszawa also demonstrated its appropriate approach to image protection and good preparation to crisis communication management. The fact that the accusations against Legia's fans were quickly proven unfounded helped, of course, a lot. The situation and, consequently, the crisis management measures would have been different, if the accusations had been confirmed. The club would then have had to face a much more serious challenge.

\section{Conclusions and summary}

Not every image-related crisis ends in failure. That was the case of the above analyzed incident. However, to achieve this, the club took a wide range of activities to put the 
crisis to an end within a few days only.

Football clubs are particularly exposed to the risk of image crises and affected by the problem of the credibility lack. The media and others tend to believe those who claim that an incident involving a football club was of the anti-Semitic nature, as the probability of such an event is high. The media (depending on the club's approach to them) can become a friend or a foe of the club, act objectively and impartially or complicate the situation even more [Rydzak, 2010, p. 120]. Taking the above into account, it is of utmost importance to take proper anticipatory measures or adopt a proactive approach when the crisis occurs. This gives a much greater chance to repeat the success of Legia Warszawa's communication team. Quick response and openness to the media were its key elements. Beside the above mentioned quick response, crisis situations, including those affecting football clubs, require the collection and verification of information coming in from various sources. Proper verification allows to establish the facts that are later announced to the public.

On the basis of Legia's case analysis and research using the IDI (in-depth interview) method, it is worth pointing out that effective responding is possible even in image-threatening situations, on condition, however, that proper procedures and actions capable of preventing the image crisis escalation are adopted. As mentioned at the beginning of this article, the loss of credibility leads to severe economic turbulences, the loss of company's market position and even bankruptcy. For this reason, difficult image-related crises cannot be underestimated. If the accusations against Legia Warszawa had been confirmed, the club would have faced not only the UEFA-imposed sanctions, but also severe losses to its image.

To sum up, it needs to be noted that success in crisis management depends also on the attitude of the management. Therefore, it is worth quoting here the opinion of Legia Warszawa's owner Dariusz Mioduski on the case: Linking football club fans with racist or anti-Semitic behavior is easy and confirms stereotypes. Especially when the Polish-Israeli relations that always attract media attention are at stake. Thus, we were aware that we were facing an image crisis at an international level. Things happened quickly and we had to react immediately. The Simon Wiesenthal Center not only issued a statement, but also forwarded an official letter to FIFA, denouncing the club to the international football authorities, thus lending credence to the incident and giving it an official dimension. FIFA's reaction in such situations is always firm. What we did immediately was to establish the crisis management team tasked with the verification of facts first of all. It soon turned out that Legia's fans were not involved in the incident and its actual nature was very different from that described in the media. No-one had checked that earlier. Using the time difference, we had to take action before opinion-forming media in the United States refer to the case and make it a global issue. That would reinforce harmful stereotypes even more. The crisis management team not only managed to verify the events within several hours of continued work, but also made the Israeli side admit that its speculations were based on unfounded gossip. Above all, however, their efforts led the Simon Wiesenthal Center to correct its official statement and withdraw the letter to FIFA. The team did a great deal of good job and it managed to win the race against time.

The words of Legia's owner and president show that the moment the first accusations appeared, the club realized that the crisis emerging outside the club was serious and might negatively affect both its image and operational stability.

Acting according to best knowledge and good practices, the club appointed the crisis management team immediately and quickly determined the actual facts related to the attack of hooligans on the Israeli club. Mr. Mioduski said that the Legia Warszawa club was aware of how serious the consequences of the accusations could be and how important it was to act quickly. The key role in the success of the case was that the facts were determined fast, which offered the club the opportunity to act efficiently. Especially that the facts were favourable for Legia. Thanks to that, Legia's statements and mes- 
sages were unambiguous and verified and the club did not need to do any guesswork or spread speculations. It also managed to avoid

a common mistake in crisis situations, that is providing unfounded information, as long as it is good for the organization. Reliable information and the speed of communication are the basis for effective crisis communication.

It is also worth noting that the crisis burst out when the Israeli club described the incident on its Facebook profile. This shows how powerful the social media is today. One piece of news released at any popular social media channel may give rise to a very serious image crisis. To tackle it, it is necessary to launch relevant crisis management procedures and involve human resources of the organization. The power of the social media is so immense that it cannot be underestimated and media monitoring needs to include the new media as well [Kaczmarek-Śliwińska, 2015, pp. 173-183].

It is difficult to prevent events such as those analyzed in this article. However, sports club can identify potential threats beforehand and develop relevant action plans in a form of the crisis management manual. It also needs to be emphasized that the crisis never ends when the media lose interest in it and the matter seems to be under control. This is the time for the post-crisis analysis of what happened, what actions and measures were taken, the evaluation of their efficiency in solving the problem. This may also be a part of the assumptions to the crisis prevention scheme. Each organization, including football clubs, need to remember that the most important objective of combating crisis situations it to protect the basic values, such as credibility and company's good reputation. Without these, it is impossible to find one's place on the market [Łaszyn, 2006, p.141].

\section{REFERENCES:}

BLACK S. (2001), Public relations., Cracow, Dom Wydawniczy ABC.

KACZMAREK-ŚLIWIŃSKA M. (2015), Public relations w zarządzaniu sytuacjami kryzysowymi organizacji. Sztuka komunikowania się, Warsaw, Difin.

ŁASZYN A. (2006), Komunikacja kryzysowa, [in:]Collectivework: Sztuka public relations. Z doświadczeń polskich praktyków., ZFPR, Warsaw.

PODRAZA U., (2008) Kryzysowe public relations, Warsaw, Difin.

POGORZELSKI S. (2010), Marketing sportowy a PR, [in:] Godlewski P., Rydzak W., Trębecki J. (ed.), Public Relations w sporcie, Wydawnictwo Sportwin sp. z 0.0., Poznan

RYDZAK W. (2010), Zarządzanie informacją w sytuacji kryzysowej, [in:] Godlewski P., Rydzak W., Trębecki J. (ed.), Public Relations w sporcie, Wydawnictwo Sportwin sp. z 0.0., Poznan.

TWORZYDŁ0 D. (2008), Kryzys, [in: ] Oędzki J., Tworzydło D. (ed.), Leksykon public relations, Newsline, RzesZOW.

TWORZYDŁ0 D. (2017), Public relations praktycznie, Rzeszow, Newsline.

Communication crisis - Legia Warszawa's reference materials obtained in the process of analyzing the presented case.

\section{ONLINE SOURCES:}

2.deloitte.com (2018), Przychody klubów Ekstraklasy w 2017 r. wyniosły 550,4 mln zl, a transfery zagraniczne zapewniły dodatkowo 145,2 mln zł [online: November 6, 2018], https://www2.deloitte.com/pl/pl/pages/ press-releases/articles/przychody-klubow-ekstraklasy-w-2017.html

bundesliga.goal.pl (2018), Kary za zachowanie kibiców w Bundeslidze [online: November 9, 2018], https:// bundesliga.goal.pl/368191-kary-za-zachowanie-kibicow-w-bundeslidze.html

ctvnews.ca (2017), Israeli soccer team targeted in 'anti-Semitic' Polish attack [online: November 14, 2018], https://www.ctvnews.ca/sports/israeli-soccer-team-targeted-in-anti-semitic-polish-attack-1.3532601

eurosport.interia.pl (2010), Serie A: kary za rasistowskie zachowanie kibiców [online: Noveber 6, 2018], https:// eurosport.interia.pl/pilka-nozna/news-serie-a-kary-za-rasistowskie-zachowanie-kibicow,nld,551704 
eurosport.interia.pl (2017), Hapoel Petah Tikwa wycofał oskarżenia wobec Legii Warszawa [online: November 9, 2018], https://eurosport.interia.pl/klub-legia-warszawa/news-hapoel-petah-tikwa-wycofal-oskarzenia-wobec-legii-warszawa,nld, 2425810

fakt.pl (2016), Ostra jatka na stadionie w Anglii. A oni czepiają się Polaków [online:November 6, 2018], https:// www.fakt.pl/sport/pilka-nozna/zamieszki-na-stadionie-podczas-meczu-west-ham-chelsea/12bqxpk

gloswielkopolski.pl (2013), Ambasador Litwy w Polsce: Myślę, że Lech Poznań powinien przeprosić [online: November 7, 2018], https://gloswielkopolski.pl/ambasador-litwy-w-polsce-mysle-ze-lech-poznan-powinienprzeprosic/ar/964928

jewishweek.timesofisrael.com (2017), Polish Soccer Fans Attack Israeli Team After Game, Two People Hurt [online: November 8, 2018], http://jewishweek.timesofisrael.com/polish-soccer-fans-attack-israeli-team-aftergame-two-people-hurt/

legia.com (2017), Centrum Wiesenthala wycofuje oskarżenia wobec Legii [online: November 19, 2018], http:// legia.com/aktualnosci/centrum-wiesenthala-wycofuje-oskarzenia-wobec-legii-56112

legia.com (2017), Simon Wiesenthal Center withdraws accusations against Legia Warsaw [online: November 19, 2018), http://legia.com/en/news/simon-wiesenthal-center-withdraws-accusations-against-legia-warsaw-56127

rmf24.pl (2013), Jest kara za kibolski transparent. Zamkną trybunę na stadionie Lecha w Poznaniu [online: November 7, 2018], http://www.rmf24.pl/sport/news-jest-kara-za-kibolski-transparent-zamkna-trybune-na-stadioni,nld, 1008779

rmf24.pl (2017), MSZ zabrało głos ws. ataku na członków drużyny Hapoel Petah Tikva [online: November 9, 2018], http://www.rmf24.pl/fakty/polska/news-msz-zabralo-glos-ws-ataku-na-czlonkow-druzyny-hapoel-petaht,nld,2425461

rmf24.pl (2018), "Okrągły stół" ws. Bezpieczeństwa na stadionach. "Urzędowy optymizm” I brak konkretów [online: November 6, 2018], https://www.rmf24.pl/fakty/polska/news-okragly-stol-ws-bezpieczenstwa-na-stadionach-urzedowy-optymi,nld,2587429

sport.dziennik.pl (2018), Lech Poznań przez burdy swoich kibiców straci kilka milionów złotych [online: November 6, 2018], http://sport.dziennik.pl/pilka-nozna/ekstraklasa/artykuly/574888,ekstraklasa-lech-poznan-kibice-pilka-nozna-kibole-race-legia.html

sporteuro.pl (2013), UEFA kara za rasizm w Lidze Mistrzów [online: November 7, 2018], https://sporteuro.pl/ uefa-kara-za-rasizm-w-lidze-mistrzow/

sport.pl (2018), Borussia Dortmund. Jest wyrok za atak na autokar z pitkarzami BVB [online: November 6, 2018], http://www.sport.pl/pilka/7,65081,24218318,borussia-dortmund-jest-wyrok-za-atak-na-autokar-z-pilkarzami. html

sport.se.pl (2011), Jak Anglicy poradzili sobie z KIBOLAMI - regularne POLOWANIE na chuliganów [online: November 6, 2018], https://sport.se.pl/pozostale/w-anglii-zniszczyli-kiboli-zelazna-piescia-aa-X3UT-ajpu-bnqV. html

sport.tvn24.pl (2017), Mecze bez publiczności, odjęty punkt. Surowe kary dla polskich klubów [online: November 6, 2018], https://sport.tvn24.pl/pilka-nozna,105/kary-komisji-ligi-pzpn-dla-cracovii-lechii-piasta-i-gornika,798637.html

usnews.com (2017), Polish Soccer Club Denies Its Fans Attacked Israelis [online: November 13, 2018], https:// www.usnews.com/news/sports/articles/2017-08-04/polish-soccer-club-denies-its-fans-attacked-israelis\#close-modal

wiesenthal.com (2017), Update: Israeli Football Team Members Attacked In Poland [online: November 19, 2018], http://www.wiesenthal.com/site/apps/nInet/content.aspx?c=IsKWLbPJLnF\&b=8776547\&ct=15002773\&notoc $=1$ 